\title{
ROLE AND ROOM FOR SOCIAL BROADCASTER WITH RADIO FARA AS AN EXAMPLE \\ Dorota Wilk
}

\begin{abstract}
The broadcaster, who uses the possibility of functioning in the broadcasting media space as a social broadcaster, ensures not only independence from power centres, political parties and commercial entities, but also full control over the broadcast content. He consciously directs ithe message to a specific group of recipients, often a niche group, providing content that commercial and public stations avoid, considering it to be unattractive. The type of programmes broadcast is strictly defined by the role it has to fulfil, the requirements set by the legislator for social broadcasters and the possibilities resulting from having such status. This has a significant impact on the place it occupies in the media radio market.
\end{abstract}

Keywords: radio, social broadcaster, license, range, listening.

\section{Introduction}

"In the first years of systemic transformation, due to the lack of legal regulations regarding the conduct of host radio activity, commercial broadcasters at first had to apply to President of the Radiocommit for permission to broadcast programs, and after the liquidation of this institution - to the Minister of Communications"[Zdrojewska, 2013]. "After 1989 the radio market has become the most dynamically developing media sector. Quite quickly radio frequencies were released for the needs of broadcasting and broadcasting became cheaper, what caused launching about 300 (mostly local stations) in very short period"[Andrzejowski, 2010]. It is written in the report of the National Broadcasting Council that since legal regulations entered into force in Poland, 55 radio stations, not paying taxes and uncontrolled in their program activities, operated without permission[www.krrit.gov.pl,1994].

\section{Radio market - listening}

Only the implementation of the Act of 29 December 1992 on radio and television led to the ordering and division of the radio market in Poland between the public broadcaster Polish Radio and its regional broadcasters and commercial broadcasters operating on the basis of concessions granted by the National Council of Radio Broadcasting and Television. "In the first concession process, in the field of private radio broadcasting, 
KRRiT[1996] granted concessions for:

- nationwide networks of private radio (Radio RMF, Radio ZET and a Catholic station Radio Maryja);

- 1 supra-regional station for the Scout Broadcasting Station. The Polish Scouting Associationobtainedthe right to run 5 broadcasting stations located throughout Poland,s big cities: Wrocław, Rzeszów, Poznań, Gdańsk and Gdynia;

- 17 regional stations;

- 133 local stations, including 46 church ones" [www.krrit.gov.pl,1996].

According to the KRRiT data [2018], six nationwide programs are currently broadcasting in Poland covering the majority of Poland with its outreach: Program 1, 2 and 3 of Polish Radio, Radio RMF FM, Radio ZET and Radio Maryja as well as trans-regional programs, including Antyradio, VOX FM, TOK FM , muzo.fm and RMF Classic and public Polish Radio 24, distributed mainly in larger cities, as well as 17 regional programs disseminated in areas corresponding to voivodships.

"In turn, local programs are about 250 group of programs with a smaller range, reaching listeners within small areas. Some of them are distributed within software networks, some are not affiliated with networks" [www.krrit.gov.pl, 2018].

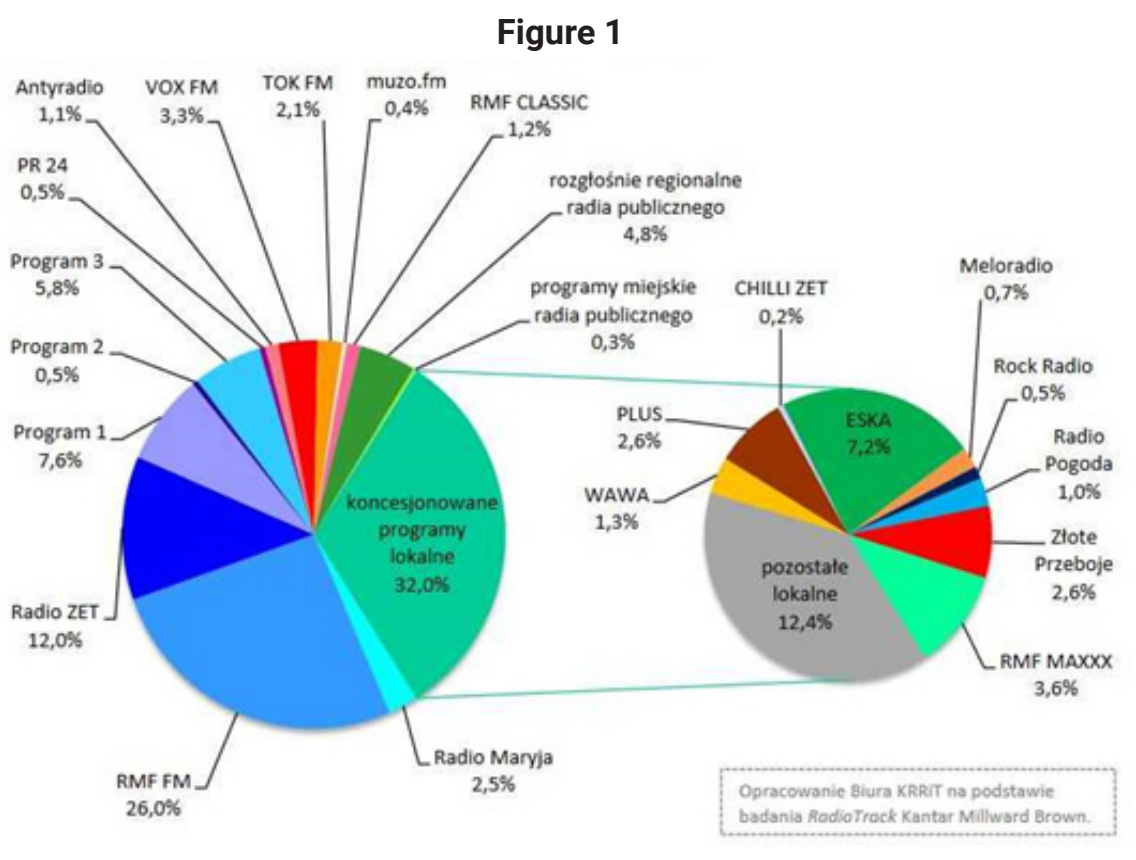

Source: KRRiT

Radio is still a medium eagerly listened to. According to an audit by Radio Track Kantar Millward Brown [2018] radio is still a medium eagerly listened to. In the first quarter of 2018 it was listened to by 71.9 percent of Polish residents, on average for 4 hours and 28 minutes a day [www.krrit.gov.pl, 2018]. The most popular programs addressed to a wide group of listeners were: those with the highest audience Radio RMF FM from 26.0\%. participation in listening time, Radio Zet and Programs 1 and 3 PR SA. along with other specialized nationwide programs: Radio Maryja and Program 2, nationwide programs covered over half of the radio market in terms of audience coverage, obtaining $54.4 \%$. participation in listening time [figure 1]. By contrast, the total share in listening to licensed local programs increased in the first quarter of 2018 to $32.0 \%$. The largest part of the local radio market, so 12.4 percent participation in the listening time, they deal 
mainly with non-affiliated broadcasters in program networks [www.krrit.gov.pl,2012]. According to the KRRiT analysts in 2001-2016, for several years there has been a tendency of increasing the audience of local programs, which have not been included in the program networks. They are distinguished by a clearer local line from programs associated in networks. They are created by local editorial teams and broadcast their own programs unlike other programs[www.krrit.gov.pl]. The group of these stations includes radio stations with the status of a social broadcaster.

\section{Who is a local broadcaster?}

In the field of audience the KRRiT analyzes and reports indicators do not separate from the radio station, the group of social broadcasters (except for the nationwide Radio Maryja), included in the so-called third sector, in addition to public and commercial broadcasters. Perhaps the reason for this is their low number, locality and program directed to niche groups, which narrows their audibility to a small number of the public. Also, information in the annual KRRiT istoo vague and reporting makes it difficult to thoroughly analyze this broadcasting sector. Urszula Doliwa[2016] made an attempt to diagnose the situation of social broadcasters in the book "Social Radio, third alongside the public and commercial radio sector", who noticed that the broadcaster is too little known. "Not only politicians do not know what the third radio sector is, representatives of institutions regulating radio activities, but very often also representatives of non-governmental organizations, or, as shown by surveys carried out in Poland - the radiographers themselves do not"[Doliwa, 2016]. "It should be mentionedhere that the first concession process carried out after the entry into force of the Radio and Television Act did not define the status of a social broadcaster" [Zdrojewska, 2013]. It appeared only in the provisions of the amended Act of February 2001 [prawo.sejm.gov.pl, 2001]. According to it, the social sender may be:

- a program that promotes educational activities, the Christian system of values, as a basis adopting universal principles of ethics and aims at strengthening the national identity,

- anyone who does not give commercial messages,

- anyone who does not charge fees for distributing, spreading or receiving its program [prawo.sejm.gov.pl].

The information included in the reports of the National Broadcasting Council [2002] shows that in the first years of the amended act on the status of a social broadcaster, mainly dioceses and Catholic parishes competed. In the first period after the definition of the social broadcaster came into force in 2001, the KRRiT granted 43 concessions for the dissemination of a socio-religious program by means of frequencies used by the Catholic Church (archdiocese, dioceses, religious orders, parishes). 24 diocesan and archdiocesan stations applied for a full advertising limit in the concession. 6 church broadcasters decided to use the $7 \%$ limit of advertisements and concurrently use the $25 \%$ discount in the concession fee provided for in the Regulation of the National Broadcasting Council of 4 February 2000 on fees for granting a license for the distribution of radio and television programs. 5 church senders applied for a $2 \%$ advertising limit, so they benefited from a $50 \%$ discount in the license fee, and two applied for an ad-free program ( $80 \%$ discount in the concession fee) without obtaining the status of a social broadcaster [www.krrit.gov.pl,2002].

Among the church senders there were six social broadcasters who did not broadcast advertisements and were exempt from the concession fee [www.krrit.gov.pl,2002]. According to KRRiT data, by the end of 2017 there were eight radio stations operating in Poland with the status of a social broadcaster[www.krrit.gov.pl./dla-nadawcow-i-operatorow/koncesje/wykaz-nadawcow-spolecznych] out of nine broadcasters with such status in the country. These were: Radio Maryja (Warsaw Province of the Congregation 
of the Most Holy Redeemer (Redemptorists), Radio Jasna Góra (Pauline Monastery Jasna Góra - Częstochowa), Radio ORTHODOXIA (Orthodox Diocese of Bialystok-Gdansk), Radio FARA (Radio of the Archdiocese of Przemyśl ), Catholic Radio Family (Archdiocese of Wroclaw), Radio Family of the Diocese of Kalisz (Diocese of Kaliska), Catholic Radio Zbrosza Duży (Roman Catholic Parish of St. John the Baptist in ZbroszaDuży), AIN KARIM Radio Skomielna Czarna (Roman Catholic parish of the Visitation NMP), Catholic Serbinów Television (Roman Catholic parish of Our Lady of Perpetual Help in Tarnobrzeg).

At the end of 2017, the Catholic Family Radio belonging to the Diocese of Wrocław asked the National Broadcasting Council to repeal the status of social broadcaster and consent to broadcast advertising [www.krrit.gov.pl, 2018, decision nr DR-51/2018$8 /-77 / \mathrm{K}]$. It was received in March 2018. As of June 25, 2018, there are eight social broadcasters in the country, seven of which are radio stations[www.krrit.gov.pl/dla-nadawcow-i-operatorow/koncesje/wykaz-nadawcow-spolecznych]. Six of them have a local outreach, one nationwide (Radio Maryja of the Redemptorist fathers). The eighth broadcaster is Serbinów Television of the Roman Catholic parish in Tarnobrzeg. The owners of seven of them are parishes, dioceses and religious congregations of the Catholic Church, one radio broadcaster belongs to the Orthodox Church [www.krrit.gov.pl/dla-nadawcow-i-operatorow/koncesje/wykaz-nadawcow-spolecznych].

The ownership status of social broadcasters operating on the media market shows the tendency, which has persisted for years, to put up this type of radio station by the Church, for which radio has become a tool for the evangelization mission and a platform for reaching a wider audience with God's word. The current legal provisions prohibiting the possibility of obtaining money from commercial broadcasts for the operation of such stations and the lack of state funding mean that social broadcasters are a negligible number among radio stations operating on the Polish media market, as illustrated by the National Broadcasting Council's lists. They are reluctant to reach for this status other than dioceses, religious congregations and parishes, making this sector the least developed sector in the broadcasting market. Despite the exemption from the concession fee for the social broadcaster, this status is unattractive for other entities, such as foundations, associations and religious associations, which could reach a selected and interested group of recipients with specific content.

List of social broadcasters (as at 25 June 2018)

\begin{tabular}{|c|c|c|c|}
\hline Lp. & Concession number & Broadcaster's name & $\begin{array}{l}\text { Programme name/ } \\
\text { agenda }\end{array}$ \\
\hline 1. & 015/K/2008-R & $\begin{array}{l}\text { Monastery of 00. Paulinów Jasna } \\
\text { Góra - Częstochowa }\end{array}$ & Jasna Góra Radio \\
\hline 1. & 068/K/2011-R & $\begin{array}{l}\text { Orthodox Diocese of Bialys- } \\
\text { tok-Gdansk }\end{array}$ & ORTHODOXIA Radio \\
\hline 2. & 075/K/2011-R & $\begin{array}{l}\text { Archdiocese of Przemyśl of the Lat- } \\
\text { in Rite }\end{array}$ & $\begin{array}{l}\text { Radio FARA - Radio } \\
\text { station in the Arch- } \\
\text { diocese of Przemyśl }\end{array}$ \\
\hline 3. & 078/K/2011-R & Kalisz Diocese & $\begin{array}{l}\text { Radio Family of the } \\
\text { Kalisz Diocese }\end{array}$ \\
\hline 4. & 104/K/2011-R & $\begin{array}{l}\text { Parafia Rzymsko-Katolicka p.w. Św. } \\
\text { Jana Chrzciciela w Zbroszy Dużej }\end{array}$ & $\begin{array}{l}\text { Zbrosza Duża Cath- } \\
\text { olic Radio }\end{array}$ \\
\hline 5. & 199/K/2013-R & $\begin{array}{l}\text { Roman Catholic Parish of the Visita- } \\
\text { tion of the Blessed Virgin Mary }\end{array}$ & $\begin{array}{l}\text { AIN KARIM Skomiel- } \\
\text { na Czarna Radio }\end{array}$ \\
\hline 6. & 301/K/2017-R & $\begin{array}{l}\text { Warsaw Province of the Congre- } \\
\text { gation of the Most Holy Redeemer } \\
\text { (Redemptorists) }\end{array}$ & RADIO MARYJA \\
\hline
\end{tabular}




\begin{tabular}{|l|l|l|l|}
\hline Lp. & Concession number & \multicolumn{1}{|c|}{ Broadcaster's name } & $\begin{array}{c}\text { Programme name/ } \\
\text { agenda }\end{array}$ \\
\hline 7. & $543 / 2013-T K$ & $\begin{array}{l}\text { Roman Catholic parish p.w. Our } \\
\text { Lady of Perpetual Help in Tarno- } \\
\text { brzeg }\end{array}$ & $\begin{array}{l}\text { Catholic Serbinów } \\
\text { Television }\end{array}$ \\
\hline
\end{tabular}

Source: KRRiT

\section{Fara Radio}

Radio Maryja was the first to use the opportunity to become a social broadcaster in 2001 [www.krrit.gov.pl, 2002]. However, media and scientists keep tabs the broadcasters for years, there is not much studies devoted to local stations with such status, and some of them have been operating on the radio market since the first concession process. One of them is Radio FARA - Broadcasting Station of the Archdiocese of Przemyśl, which for 14 years has been active in the media space as a social broadcaster. It should be noted here that the status of the social broadcaster has its relation both in the ownership structure of the radio station, its programming offer and financing method, as well as in the engagement of the listeners in the creation of broadcasted content. Available documents [KRRiT, concessions nr 0014/94-Rand 0013/94-R, 15.07.1994]show that in 1994 the Metropolitan Curia in Przemyśl (as a legal entity) obtained a license for broadcasting programs for two local stations of the Catholic Church in the Przemyśl diocese: Radio Maryja - Krosno ${ }^{2}$ (the later name is FARA - Catholic Radio Krosno Radio Broadcasting Station of the Archdiocese of Przemyśl, Saint John of Dukla) [www.krrit.gov.pl, decisionnr DK-197/97-2/14, 15.10.1997] and Radio Ave Maria in Jarosław ${ }^{3}$ with transmitters in Miejsce Piastowe and Jarosław. The KRRiT granted these concessions for seven years.

Both broadcasters defined their profile from the beginning as socio-religious. However, they are different in the method of financing the activity. Radio Maryja - Krosno raised money for functioning from the broadcast of commercials and sponsored programs, meanwhile Ave Maria radio in Jarosław, from the very beginning, did not issue paid broadcasts, keeping this state until the status of social broadcaster was granted [Bienia, July 20,2018]. In 2001, the concessionaire decided to merge both stations into one diocesan radio station. In March 2001, the Archdiocese of Przemyśl of the Latin Rite filed with the National Broadcasting Council an application for the granting of a license for the distribution of a radio program under the name Radio FARA - Broadcasting Station of the Archdiocese of Przemyśl. According to the concession issued on July 12, 2001, September 19, 2001 by the decree of Fr. Archbishop JózefMichalik, who 'due to new needs and appreciating the several years' achievements of both stations', was established a station in the Archdiocese of Przemyśl based in Przemyśl and broadcasting studios in Jarosław and Krosno'. The station's director was given the task of launching a radio studio in Przemyśl at that time ${ }^{4}$.

Under the terms of the concession, the broadcasting time was set: no less than 13 hours a day, radio programs and forms had to occupy not less than 12 percent of the

\footnotetext{
2 On the basis of the agreement of March 3, 1994 on the principles of using Radio Maryja-Krosno concluded between the Warsaw Province of the Congregation of Redemptorists and the Archdiocese of Przemyśl of the Roman Catholic Church, in the first years the concessionaire made his frequency available to Radio Maryja. In 1997 the Archdiocese of Przemyśl decided to broadcast its own program, in the same year changed the name of the radio station from Radio Maryja-Krosno to FARA - Catholic Radio Krosno Radio of the Archdiocese of Przemysl under the invocation of St. John of Dukla, referring to the Parish Church in Krosno, where it was located.

3 The founder of Ave Maryja radio in Jarosław was father Marian Rajchel, parish priest of the Queen of Poland parish in Jarosław, where he organized the first radio studio.

$4 \quad$ Due to technical problems, the studio in Przemyśl started broadcasting in 2006, until then the programme from the studio in Jarostaw had been broadcasted in this area.
} 
weekly broadcasting time, and advertising 15 percent of daily broadcasting. It caused charging the Archdiocese with a fee for granting a license in the amount of approximately 79.000 zloty[www.krrit.gov.pl, concession nr 008/P/2001-R, 12.07.200]. On July 31, 2001 , the licensee asked the National Broadcasting Council to correct the limit of commercials. As a result of the KRRiT error, the ad emission indicators were inflated.

From the beginning, the licensee requested to specify the size of two percent. At the request of the Archdiocese, the content limit was reduced, which caused lower concession fee. It has been determined that ads will not take more than 2 percent of the daily broadcast time of the program and no more than 3 minutes per hour [www.krrit.gov.pl, decision nr DK-159/2001-1/008/P, 14.08.2001]. On a final note, the Archdiocese paid 39.000 zloty for the license. Thanks to frequencies that they had and two transmitters in Jarosław and Czarnorzek near Krosno (moved from Miejsce Piastowe) [www.krrit.gov. $\mathrm{pl}$, decision nr DK-067/98-3/14, 21.04.1998], it covered at that time an area of $54 \mathrm{com}-$ munes and cities (partially or entirely), with 431.000 people[www.krrit.gov.pl, decision $\mathrm{nr}$ DK $-159 / 2001-1 / 008 / \mathrm{P} / 2001,14.08 .2001]$. As a commercial broadcaster, studio in Krosno, which was existing for four years, decided to continue the existing method of financing by broadcasting advertisements, sponsored magazines, media patrons, agreements with communes and districts regarding the promotion of these units, as well as through rebounds in parishes, offerings from listeners, curia's refunds and subventions [Radio Fara, 20 July 2018]. Broadcasting station in Jarosław was still free from ads, do not conduct business activity and based its activity on the rebounds of the parishioners [Radio Fara, 20 July 2018].

After three years of operating on the market as a commercial broadcaster, the Archdiocese came out on November 19, 2003 to get the status of a social broadcaster to Radio FARA. Radio received it in January 2004 [www.krrit.gov.pl, decision nr DK 007/2004 $2 / 008 / P, 19.01 .2004]$.In the justification for granting such status, the applicant indicated that he is:

- Promoting educational activities

- Respecting Christian value system;

- Not transmitting ads, telesales and sponsored auditions;

- Not charging fees for transmitting, broadcasting or receiving program

The concessionaire noted that getting the title of a social broadcaster would reduce the costs of its operation and conduct a wider educational activity for local listeners [www.krrit.gov.pl.Decision nr DK 007/2004 - 2/008/P, 19.01.2004]. In 2003, at the broadcaster's request, the KRRiT agreed to move the transmitter from Jarosław to Średnia near Przemyśl [www.krrit.gov.pl.Decision nr DK-228/2003, 15.09.2003.] land at the beginning of 2004, thanks to the KRRiT's consent to extend the range of the broadcasting station, the station extended its range and covered the area inhabited by about 600 thousand people [www.krrit.giv.pl, decision nr DK - 008/2004 - 3/008/P, 20.01.2004].

In 2007 KRRiT renew FARA's Radio concession to 2011 because of some changes in the act, which will renew it for 10 years [www.krrit.gov.pl. decision nr 438/2007 5/008/P, annex to concession Nr 008/P/2001-R, 12.07. 2001]. In 2011, the Archdiocese received a license for the next 10 years to broadcast the program as a social broadcaster [www.krrit.gov.pl.Concession nr 075/K/2011, 26 .04.2011]. The station uses two frequencies: $98.2 \mathrm{MHz}$ - a transmitter in Średnia near Przemyśl and $104.5 \mathrm{MHz}$ - a transmitter in Czarnorzeki near Krosno. According to the provisions, both broadcasting stations cover, in whole or in part, the area of 61 communes and cities[www.krrit.gov.pl.Concession nr 075/K/2011, 26 .04.2011.] on the territory of the former provinces: Przemyśl, Krosno and Rzeszów.

The main goal of the Radio FARA is to support the local Church in the mission of evangelization [www.krrit.gov.pl.Concession nr 008/P/2001-R, 12.07.2001]. The broadcaster emphasizes that he is not associated with any political, economic or social force. 
It mainly broadcasts prayer, formation, cultural and social programs. It does not broadcast advertisements, sponsored materials or electoral broadcasts[przemyska.pl./program-radio-fara, as at 26.07.2018]. From the beginning of its activity, it has consistently and consciously avoided broadcasting content related to politics [Bienia, July 20,2018].

The perception of their role, and thus the formulation of the programming offer, was described by Krzysztof Rzepka, the former director of Radio FARA in an interview given to Tygodnik Niedziela [2013]. In his view, the radio as a medium in the common Polish sense has been overloaded with commercial and entertainment connotations. "We meet every day with astonishment or accusations that some content or songs will not be heard. Meanwhile, as shown in recent years, the radio that closes in the circle of church events, possibly cultural and social, is not only marginalized, but gains new listeners. Radio FARA has consistently narrowed the circle of its activities and interests to the local Church, thanks to which we do not have to push ourselves with others" [Rzepka 2013, niedziela.pl].

The spoken word and Christian music occupy a greater part of the airtime. The constant element present on the air is prayer, recited every morning for 45 minutes, moreover, a holy mass is broadcast - two times for 40 minutes, in the afternoon The Angelus is hosted - 15 minutes, The Chaplet of Divine Mercy - 20 minutes, rosary - 35 minutes, The Jasna Góra appeal - 20 minutes.As a local broadcaster whose scope is narrowed to the southern and eastern voivodship Podkarpackie focuses on local events. It shows small initiatives, pastoral events, parish festivals, carol's concerts. Every year it accompanies pilgrims to Jasna Góra, because it recognizes its duty to report live on the Przemyśl pilgrimage to those who cannot go to Częstochowa.

At this point, it should be noted that Radio FARA does not narrow down its offer to the mature audience, it performs the educational role assigned to the social broadcaster through a program offer covering health and sobriety advice [Bienia, July 20, 2018], programs for children, every day it is $\mathbf{3 0}$ minutes broadcast, as well as programs for young people, which is provided by the air time twice a week [Kozak, July 6, 2018]. As Michat Drożdż notes [2009], Catholic radios are trying to work out their own style with more or less effectiveness, showing that 'catholicity' does not mean and should not mean in any way mediocrity, haphazard, lack of attractiveness [Drożdż, 2009].

Radio offers content that is not broadcast by public and commercial broadcasters, thus filling the gap on the market of social radio, directing its program offer to a local recipient, profiled to the circle of people associated with the Church's teaching.Pawet Stępka rightly points out that commercial local broadcasters, although they also address their offer to the local community, the aim of their activity is first of all the economic result, which limits the possibility of strong involvement in the life of the community. In this case, the social objectives are subordinated to the objectives of economic, which distinguishes them significantly from third party media[ Stępka, 2007]. "A characteristic phenomenon in recent years is the entry in the Internet field radio operations. Traditional stations have started broadcasting this way" [Godzić]. Radio FARA did the same. The launch of the radio's website in 2005 allowed it to go beyond the area depending on the range of the transmitters [Kozak, July 6, 2018]. In this way, radio extended the area of impact outside the area designated by the technical conditions in the concession. The purchase of a transmission car in 2017 and cameras allowed the station to broadcast an image via the Internet. The first live broadcast of the July pilgrimage 2018 from Przemyśl to Jasna Góra was watched by 600 people on the Internet [Bienia, July 20, 2018]. The next step in expanding the FARA radio will be broadcasting hourly information services, currently due to the limited number of employees, the broadcaster emits only three times a day messages from Vatican Radio. The concessionaire admits that the status of social broadcasters has a significant impact on the way of employing people who create programs and run programs. Due to the limited financial and human resources, and what is connected with the possibility of reaching many places in the Archdiocese, volunteers 
have become an important element in the creation of the broadcasting program. Fulltime radio employees, employed by Archdiocese Przemyska, who owns the station, only 4.5 part-time for lay people, the rest are priests and nuns delegated to work on the radio as part of a pastoral mission and volunteers cooperating with studies in Przemyśl, Jarosław and Krosno [Bienia, July 20, 2018]. The radio station has been trying to gather constant listeners and supporters for years, which is why it established the FARA Circle of Friends of Radio. Members of the Circle are obliged to pray for the Radio, the people who work in it, undertaken initiatives and current intentions of the radio; creating a group of co-workers, volunteers and correspondents to inform the editorial office about important religious, patriotic and local events in their communities, submit program suggestions and help in enterprises undertaken by the Radio, permanent financial support for Radio [przemyska.pl/program-radio-fara, at 26.07.2018].

What distinguishes a social broadcaster from a commercial broadcaster is, as Stępka[2007]writes, a specific programme offer addressed to the broadcaster's community, which is obliged to ensure the broadest possible participation of representatives of a given community at different stages of broadcasting activity. "Despite the fact that modern media are becoming more and more interactive, the relations between the third sector media and their recipients are special. In many cases, broadcasting activities are conducted directly by representatives of a given community, often free of charge"[Stęp$\mathrm{ka}, 2007]$.

The status of a social broadcaster involves the need to raise money for activities in a different form than from the profit from advertising and sponsored programs. The sender does not conceal that such status is a cut off from commercials and commercial contracts. The radio station is kept only from the sacrifices of the faithful [przemyska. $\mathrm{pl} /$ program-radia-fara, at 26.07.2018]. Among others, from donations made to the account or transferred as 1 percent of the tax deduction. The sender has launched for this purpose a special platform on the website with several payment options [ibidem]. It also runs fundraisers under the Jarosław's churches [Kozak, July 6, 2018], and once a year in all parishes of the Przemyśl diocese [Bienia, July 20,2018]. Narrowing the possibility of raising money affects, to a large extent, the range of the station's influence as well as the extension in its program profile.

Although the religious nature and locality may be an asset of Radio FARA, the shortage of staff caused by the reduction of funds slows down the development of this radio station, extending its programme and increasing the content of not only local and supra-local content. On December 12, 2016, the station applied to the National Broadcasting Council for launching an additional low-power transmitter for the new frequency in Przemyśl and for solving the problem of poor program audibility in and around Leżajsk[Radio Fara, letter addressed to the National Broadcasting Council by the director of Radio FARA, Fr Andrzej Bienia, 12.12.2016].There are places in the transmitter area where the radio station is not audible due to the terrain [Bienia, July 20, 2018].

It should be noted at this point that technical difficulties in the reception of a radio station, financial situation and staffingmay be the factors influencing the station's listening rates, and thus its position among the radio stations received in the diocese.

What is the position of Radio Fara on the radio media market? According to the latest research Radio Track Kantar Millward Brown conducted at the turn of November 2017 and April 2018 in the area of these three former voivodships, the daily coverage of Radio FARA (percentage of people in a given population who listened to the program at least once a day) was 1.2 percent, which is 16 thousand inhabitants, and 4.9 percent, or 66 thousand people questioned, who know the radio in their area, just mentioned this radio station (tables 1 and 2 ). 
Table 1

\begin{tabular}{|l|c|c|c|c|}
\hline $\begin{array}{c}\text { Radio Fara } \\
\text { November } \\
\begin{array}{c}\text { 2017-april } \\
\text { 2018) }\end{array}\end{array}$ & $\begin{array}{c}\text { Supported } \\
\text { Knowledge }\end{array}$ & $\begin{array}{c}\text { Weekly out- } \\
\text { reach }\end{array}$ & Daily outreach & $\begin{array}{c}\text { Spontaneous } \\
\text { knowledge }\end{array}$ \\
\hline $\begin{array}{l}\text { Prze m y kie } \\
\text { voivodeship }\end{array}$ & $52,1 \%$ & $12,0 \%$ & $1,7 \%$ & $9,6 \%$ \\
\hline $\begin{array}{l}\text { Krośnieńskie } \\
\text { voivodeship }\end{array}$ & $48,8 \%$ & $5,4 \%$ & $2,2 \%$ & $7,2 \%$ \\
\hline $\begin{array}{l}\text { Krośnieńskie } \\
\text { and Przemys- } \\
\text { kie voivodeship }\end{array}$ & $50,3 \%$ & $9,0 \%$ & $2,0 \%$ & $8,3 \%$ \\
\hline $\begin{array}{l}\text { Krośnieńskie, } \\
\text { Prze myskie, } \\
\text { Rzeszowskie } \\
\text { voivodeship }\end{array}$ & $27,4 \%$ & $5,1 \%$ & $1,2 \%$ & $4,9 \%$ \\
\hline
\end{tabular}

Source: Radio Track - KBR Kantar Millward Brown

Table 2

\begin{tabular}{|l|c|c|c|c|}
\hline $\begin{array}{c}\text { Radio Fara } \\
\text { November } \\
\begin{array}{c}\text { 2017-april } \\
\text { 2018)* }\end{array}\end{array}$ & $\begin{array}{c}\text { Supported } \\
\text { Knowledge }\end{array}$ & $\begin{array}{c}\text { Weekly out- } \\
\text { reach }\end{array}$ & Daily outreach & $\begin{array}{c}\text { Spontaneous } \\
\text { knowledge }\end{array}$ \\
\hline $\begin{array}{l}\text { Prze my s kie } \\
\text { voivodeship }\end{array}$ & 174 & 40 & 6 & 32 \\
\hline $\begin{array}{l}\text { Krośnieńskie } \\
\text { voivodeship }\end{array}$ & 193 & 25 & 9 & 29 \\
\hline $\begin{array}{l}\text { Krośnieńskie } \\
\text { and Przemys- } \\
\text { kie voivodeship }\end{array}$ & 366 & 65 & 14 & 61 \\
\hline $\begin{array}{l}\text { Krośnieńskie, } \\
\text { Prze myskie, } \\
\text { Rzeszowskie } \\
\text { voivodeship }\end{array}$ & 372 & 69 & 16 & 66 \\
\hline
\end{tabular}

*in thousands.

Source: Radio Track - KBR Kantar Millward Brown research

According to Radio Track research conducted in the former voivodeship of Przemyśl at September 2016 - December 2017, the largest group of people listening to FARA Radio were people in age of 40-59 (56 percent of all listeners) and people living in the countryside (56 percent), the largest group there were men (63 percent) (table 3 ).

Radio Track's research showed that the percentage of people aged 15-24 listening to the radio make 12 percent of the listeners of this radio station. The smallest group are people aged 25-39 and residents of cities with 20 to 99 thousand people (table 3). 
Table 3

\begin{tabular}{|c|c|c|c|c|c|c|c|c|}
\hline $\begin{array}{l}\text { September } \\
\text { 2016-Decem- } \\
\text { ber } 2017 \text { * }\end{array}$ & $\begin{array}{l}\text { Polskie } \\
\text { Radio } \\
\text { Rzeszów }\end{array}$ & $\begin{array}{c}\text { Radio Eska } \\
\text { Przemyśl }\end{array}$ & $\begin{array}{c}\text { Radio Fara } \\
\text { Przemyśl }\end{array}$ & $\begin{array}{c}\text { Program } 1 \\
\text { Polskiego } \\
\text { Radia }\end{array}$ & $\begin{array}{c}\text { Program } 3 \\
\text { Polskiego } \\
\text { Radia }\end{array}$ & $\begin{array}{l}\text { Radio } \\
\text { Maryja }\end{array}$ & $\begin{array}{c}\text { Radio RMF } \\
\text { FM }\end{array}$ & Radio Zet \\
\hline \multicolumn{9}{|c|}{ size of town } \\
\hline $\begin{array}{l}\text { Cities } \\
20-99000\end{array}$ & $16 \%$ & $28 \%$ & $20 \%$ & $28 \%$ & $37 \%$ & $22 \%$ & $23 \%$ & $32 \%$ \\
\hline $\begin{array}{l}\text { Cities } \\
\text { up to } 20000\end{array}$ & $8 \%$ & $7 \%$ & $24 \%$ & $11 \%$ & $24 \%$ & $9 \%$ & $14 \%$ & $9 \%$ \\
\hline village & $77 \%$ & $65 \%$ & $56 \%$ & $61 \%$ & $40 \%$ & $70 \%$ & $63 \%$ & $59 \%$ \\
\hline \multicolumn{9}{|c|}{ age } \\
\hline $15-24$ years & $8 \%$ & $43 \%$ & $12 \%$ & $9 \%$ & $6 \%$ & $15 \%$ & $19 \%$ & $19 \%$ \\
\hline $25-29$ years & $14 \%$ & $32 \%$ & $10 \%$ & $20 \%$ & $20 \%$ & $20 \%$ & $32 \%$ & $35 \%$ \\
\hline 40-59 years & $37 \%$ & $17 \%$ & $56 \%$ & $31 \%$ & $47 \%$ & $31 \%$ & $39 \%$ & $39 \%$ \\
\hline $60-75$ years & $41 \%$ & $7 \%$ & $22 \%$ & $40 \%$ & $27 \%$ & $34 \%$ & $10 \%$ & $8 \%$ \\
\hline \multicolumn{9}{|c|}{ sex } \\
\hline man & $58 \%$ & $45 \%$ & $63 \%$ & $43 \%$ & $45 \%$ & $35 \%$ & $50 \%$ & $60 \%$ \\
\hline woman & $42 \%$ & $55 \%$ & $37 \%$ & $57 \%$ & $55 \%$ & $65 \%$ & $50 \%$ & $40 \%$ \\
\hline
\end{tabular}

Listening to Radio FARA is illustrated by radio market research conducted from the end of 2016 to April 2018 by Radio Track in the former provinces of Krosno and Przemyśl. Out of 14 radio stations listened to by listeners in these areas, Radio FARA is ranked 12th in terms of daily coverage (see Table 4 ) and 12 out of 15 radio stations in terms of participation in listening time (table 5).

Daily coverage and listening time surveys illustrate the dominant position on the local market of RMF FM (in the period from XI 2017 to IV 2018) (tables 4 and 5). The threshold also holds high positions in listening rates. 1 Polish Radio and Radio Zet. In total, in the six-month period from XI 2017 to IV 2018, the audience of these three stations in the studied area amounted to $63.1 \%$, while seven stations transmitting local content (including the regional public radio station) listened to a total of $25.2 \%$ of the surveyed. Among them, Radio Fara reached only $0.8 \%$, which placed it in this respect on the last position among the radio stations broadcasting licensed local programmes, ahead of Radio Wawa Rzeszów, Eska Rzeszów and Eska Przemyśl, Polskie Radio Rzeszów, Trendy Radio Krosno, RMF MAXXX Krosno. In terms of audience, the stations with a national coverage were weaker than Radio Fara: Polish Radio 24, Prog.2 of the Polish Radio, and the regional network of Radio Złote Przeboje. It is worth noting at this point that Radio Fara was one of the two religious stations surveyed in the surveyed area, the other was Radio Maryja, which recorded an audience of 3.5 per cent during this period.

However, there has been a recent upward trend in the number of listeners.Compared to the same period, i.e. from XI 2016 to IV 2017, the audibility of stations increased by 0.3 per cent of the rate, which was 0.5 per cent at that time and the daily coverage increased by 0,8 per cent (was 1,2 per cent) (tables 4 and 5 ). This may indicate an increase in listeners' demand for a radio station profiled around the Church and local events. 
Table 4

\begin{tabular}{|l|c|c|c|}
\hline \multicolumn{1}{|c|}{ Daily range } & & & \\
\hline & XI 2016-IV 2017 & V 2017-X 2018 & XI 2017-IV 2018 \\
\hline RMF FM & $39,4 \%$ & $37,5 \%$ & $36,2 \%$ \\
\hline Radio ZET & $17,8 \%$ & $14,6 \%$ & $18,5 \%$ \\
\hline Polskie Radia pr.1 & $13,1 \%$ & $12,1 \%$ & $18,5 \%$ \\
\hline Radio Wawa(Rzeszów) & $10,5 \%$ & $7,8 \%$ & $10,5 \%$ \\
\hline Polskie Radio Rzeszów & $8,6 \%$ & $9,1 \%$ & $9,2 \%$ \\
\hline ESKA Rzeszów & $8,8 \%$ & $10,7 \%$ & $8,9 \%$ \\
\hline Prog.3 Polskiego Radia & $9,5 \%$ & $6,7 \%$ & $5,1 \%$ \\
\hline Radio Maryja & $5,6 \%$ & $4,8 \%$ & $5,0 \%$ \\
\hline ESKA (Przemyśl) & $6,7 \%$ & $3,1 \%$ & $4,7 \%$ \\
\hline RMF MAXXX (Krosno) & $1,4 \%$ & $1,3 \%$ & $2,7 \%$ \\
\hline Radio Trendy (Krosno) & $3,9 \%$ & $4,1 \%$ & $2,0 \%$ \\
\hline Radio Fara (Przemyśl) & $1,2 \%$ & $0,8 \%$ & $2,0 \%$ \\
\hline Złote Przeboje (Rzeszów) & $1,3 \%$ & $1,2 \%$ & $1,4 \%$ \\
\hline Prog.2 Polskiego Radia & $0,4 \%$ & $0,6 \%$ & $0,8 \%$ \\
\hline
\end{tabular}

Source: Radio Track Kantar Millward Brown

Table 5

\begin{tabular}{|l|c|c|c|}
\hline \multicolumn{1}{|c|}{$\begin{array}{c}\text { Participation } \\
\text { in listening time }\end{array}$} & XI 2016-IV 2017 & V 2017-X 2018 & XI 2017-IV 2018 \\
\hline RMF FM & $37,3 \%$ & $39,0 \%$ & $37,5 \%$ \\
\hline Prog.1 Polskiego Radia & $11,5 \%$ & $12,2 \%$ & $13,3 \%$ \\
\hline Radio Zet & $9,3 \%$ & $9,8 \%$ & $12,3 \%$ \\
\hline Polskie Radio Rzeszów & $7,5 \%$ & $7,5 \%$ & $8,1 \%$ \\
\hline Radio Wawa(Rzeszów) & $7,4 \%$ & $5,2 \%$ & $6,7 \%$ \\
\hline Prog.3 Polskiego Radia & $7,3 \%$ & $6,0 \%$ & $5,6 \%$ \\
\hline Radio Eska (Rzeszów) & $5,6 \%$ & $8,6 \%$ & $5,5 \%$ \\
\hline Radio Maryja & $2,6 \%$ & $3,4 \%$ & $3,5 \%$ \\
\hline Radio Eska (Przemyśl) & $5,7 \%$ & $1,0 \%$ & $1,6 \%$ \\
\hline Trendy Radio (Krosno) & $3,2 \%$ & $3,5 \%$ & $1,3 \%$ \\
\hline RMF MAXXX (Krosno) & $0,7 \%$ & $1,0 \%$ & $1,2 \%$ \\
\hline Radio Fara (Przemyśl) & $0,5 \%$ & $0,3 \%$ & $0,8 \%$ \\
\hline Polskie Radio 24 & $0,0 \%$ & $0,5 \%$ & $0,6 \%$ \\
\hline Prog.2 Polskiego Radia & $0,1 \%$ & $0,2 \%$ & $0,3 \%$ \\
\hline Radio Złote Przeboje & $0,3 \%$ & $0,3 \%$ & $0,3 \%$ \\
\hline
\end{tabular}

Source: Radio Track Kantar Millward Brown

Radio Fara is a part of the programme tasks proposed to the National Broadcasting Council in 2012, which should be carried out by a social broadcaster, and formulated by the Urszula Doliwa and participants of the Regional Conference on Civil Media organized 
by the Elbląg Association of Non-Governmental Initiatives in 2012: "gives the local community the opportunity to participate in the creation and management of the programme, to express on air the values desired by the Church, but ignored or avoided by commercial and public stations, which find them unattractive; gives its listeners a sense of belonging to a specific social group, identifying with it, satisfying the needs of people strongly associated with the Church and strongly attached to the decalogue; young people to acquire practical media skills by involving them in the creation of radio programmes and thus fulfils the educational requirement imposed on the social broadcaster by the legislator" [Doliwa, 2012].

This Catholic radio station is an example of the use of radio as a tool to carry out certain tasks assigned to the Church. The Church is more and more eager to use modern mass media. In the process of evangelization she uses both traditional media (press) as well as modern media, entering the field of influence of electronic media and more and more boldly using television, radio, the Internet, including social media, as a tool in pastoral work. Radio has become an attractive platform for the Church to convey the Word of God. One of the benefits of the status of a social broadcaster is the exemption from the license fee, which is often the basic barrier to the creation of local radio stations. The status of a social broadcaster ensures Radio's independence from power centres, political parties and commercial entities. Deprived of pressure and influence of advertisers, it is not subject to restrictions and may focus on broadcasting only content close to the Church and profile the programme around specific values.

The limited financial resources available to the social broadcaster, resulting from the ban on obtaining them from transmitting paid broadcasts, have a significant impact on the range of influence of the presented radio station and its place among radio broadcasters. For example, by a limited number of journalists and correspondents. The local character of Radio Fara, profiled around the Church's teachings, restricts its reach and audience to a narrow group of recipients, so it is difficult for it to compete not only with nationwide stations with a larger range and diversified programme offer, but also with local commercial radio stations. An additional obstacle is the technical problems related to the reception of stations in some regions of the Podkarpacie region. This is demonstrated by Radio Track's research, which shows its small share of the radio market, niche audibility, as well as its daily reach, although the latest ones also show a slight increase in the audience of this station (turn of 2017 and 2018), which may indicate that it finds listeners looking for specific content that commercial broadcasters are not interested in.

The lack of an additional source of financing, i.e. money from commercial broadcasts, as well as support from state subsidies, limits the expansion of Radio's programming offer with both local and national content. Polish legislation in this area does not encourage the development of the third sector of broadcasters, i.e. social broadcasters, which results in a very small number of broadcasters benefiting from this status and their close relationship with the Church, which, as one of the few entities, is able to finance the activities of broadcasters through donations from the faithful.

In 2012, the National Broadcasting Council conducted consultations on amendments to the Broadcasting Act and granting the social broadcaster the right to broadcast advertising messages in a limited scope and to use them for broadcasting or statutory activities. At that time, the National Broadcasting Council noticed that the current legal regulations do not create favourable conditions for the development of community media, and the experiences of European countries indicate the need for this group to fill the gap between public and commercial media [www.krrit.gov.pl, 2012].

The right-wing Members of Parliament were in favour of a change that would benefit social broadcasters at the time. However, it did not decide to introduce them. The reason for this can be seen in the wave of criticism of the biggest social broadcaster, i.e. the nationwide radio station Radio Maryja, which is politically involved, the controversies aroused and still aroused by this broadcaster, as well as in the particular interests 
of various parties and groups. At this point, one may be tempted to say that they could influence on the abandonment of changes in Polish legislation that would lead to the development of the third sector of radio broadcasting, pushing social broadcasters to a marginal group of radio stations.

The question remains open as to whether those currently in power will introduce favourable legal solutions that will contribute to the development of this type of media on a larger scale.

\section{References}

ANDRZEJOWSKIJ.(2010), Changes in regional radio stations of Polish Radio after 1989, (in:) Nierenberg B. (ed), Radio and newspapers, transformation of Polish regional media after 1989, publishing houseAdam Marszałek, Toruń.

DOLIWA U. (2016), Social radio third alongside public and commercial broadcasting sector, Wydawnictwo Uniwersytetu Warmińsko-Mazurskiego w Olsztynie.

FR. MICHAŁ KOZAK. (2018), director of the FARA Radio studio in Jarosław, an interview in July 6, 2018, Jarosław.

FR. ANDRZEJ BIENIA. (2018), director of Radio FARA, an interview in July 20, 2018, Przemyśl.

STĘPKA P. (2007), Media development of the third sector in Europe, Zeszyty Prasoznawcze, NR 1-2, Kraków.

ZDROJEWSKA K.(2013), Radio market in Poland after 1989. From the firstcommercialstations to formatted networks, (in:) Pokorna-Ignatowicz K.(ed), Polish media system 1989-2011, Kraków.

DROŻDŻ M. (2009), The phenomenon of Catholic radio in the area of freedom[w:]Nierenberg B, Radio and newspapers, Transformation of Polish regional media after 1989.,publishinghouseAdam Marszałek, Toruń.

DZIERŻYŃSKA-MIELCZAREK J. (2012), The radio market in Poland in 2001-2011, Zeszyty Prasoznawcze R.LV, nr 4 (212), Kraków.

GODZIĆ W.The situation of Polishaudiovisual media in 1989-2008, Szkoła Wyższa Psychologii Społecznej.

NIERENBERG B. Radio and newspapers. Transformation of Polish regional media after 1989,publishinghouse Adam Marszałek, Toruń.

RADIO FARA. Statement of the Metropolitan Curia in Przemyśl of 28 February 2001, archive of Radio FARA, Przemyśl.

RADIO FARA. (2018), Economic and financial study, Annex to the concession application, FARA-Catholic Radio Krosno from March 6, 2001, Radio FARA archive, Przemyśl.

RADIO FARA. (2018), Letter addressed to the National Broadcasting Council by the director of Radio Fara, Przemyśl.

\section{Internet Source}

NIEDZIELA.PL. (2013), Fr. Krzysztof Rzepka, Good news radio, Niedziela Ogólnopolska, No. 30/2013, p. 46-47]. PRZEMYSKA.PL/program-radio-fara, as at 26.07.2018.

PRAWO.SEJM.GOV.PL, Act of 1 February 2001 amending the Broadcasting Acts, Journal of Laws of 2001 No. 42

WWW.KRRIT.GOV.PL.Local radio programmes 2001-2016, Warsaw.

WWW.KRRIT.GOV.PL.(2012),Public consultation on amendments to the Broadcasting Act concerning the social broadcaster, Warsaw.

WWW.KRRIT.GOV.PL. (1994),Report on the KRRiT activity from the annual period of activity together with information and basic problems of radio and television broadcasting,Warsaw.

WWW.KRRIT.GOV.PL. (1996),KRRiT report on the annual period of activity together with information on basic problems of radio and television, Warsaw.

WWW.KRRIT.GOV.PL. (2002),KRRiT report on the annual period of activity, Warsaw.

WWW.KRRIT.GOV.PL. (2018),Market share and size of radio audience in the first quarter of 2018,Warsaw.

WWW.KRRIT.GOV.PL, (2012),DoliwaU., Response to Jan Dworak, President of the KRRiT, Olsztyn. 
WWW.KRRIT.GOV.PL.(2012), Public consultation on amendments to the Broadcasting Act concerning the social broadcaster, Warsaw.

WWW.KRRIT.GOV.PL, Local radio programmes 2001-2016, Warsaw.

WWW.KRRIT.GOV.PL,CONCESSIONS Nr 0014/94-R i 0013/94-R, 15.07.1994

WWW.KRRIT.GOV.PL,CONCESSION Nr 008/P/2001-R, 12.07.2001

WWW.KRRIT.GOV.PL,CONCESSION Nr 075/K/2011, 26 .04.2011.

WWW.KRRIT.GOV.PL,DECISION Nr DK-197/97-2/14, 15.07.1994

WWW.KRRIT.GOV.PL,DECISION Nr DK-067/98-3/14, 21.04.1998

WWW.KRRIT.GOV.PL,DECISION Nr DK - 159/2001 - 1/008/P/2001, 14.08.2001

WWW.KRRIT.GOV.PL,DECISION Nr DK 007/2004 - 2/008/P, 19.01.2004

WWW.KRRIT.GOV.PL,DECISION Nr DK-228/2003, 15.09.2003

WWW.KRRIT.GOV.PL,DECISION Nr438/2007 - 5/008/P, 12.07. 2001

WWW.KRRIT.GOV.PL,DECISION Nr 075/K/2011, 26 .04.2011 